\title{
Research on the Burden of Proof in Litigation of Abuse of Dominant Market Position
}

\author{
Jiyin Chen and Lanfang Fei*
}

\author{
Jinan University, Guangzhou, China \\ *Corresponding author. Email: 571812024@qq.com
}

\begin{abstract}
From the empirical analysis, we can learn that there are many problems in the judicial practice of litigation of abuse of dominant market position, such as the difficulties of plaintiffs in proving their case, the heavy burden of proof and the extremely low success rate. However, the main reasons for these difficulties are the inadequacy of the existing provisions on reducing the burden of proof and the lack of the plaintiff's ability to collect evidence. Therefore, it is necessary to improve the existing provisions on reducing the burden of proof in order to give full play to the value of private antitrust litigation and to reduce the burden of proof on the plaintiff.
\end{abstract}

Keywords: Abuse of dominant market position, Distribution of burden of proof, Anti-monopoly law.

\section{THE CURRENT PROVISIONS ON THE ALLOCATION OF BURDEN OF PROOF IN THE LITIGATION OF ABUSING MARKET DOMINANT POSITION}

The burden of proof is considered to be the backbone of civil litigation. It is the essence of the risk of losing the case for the parties. [1] However, the system of allocation of the burden of proof is the core element of the burden of proof. It is of great importance in civil litigation. [2] The success or failure of the final outcome of the litigation even depends on whether its allocation is scientific or not. Its importance is self-evident to both the plaintiff and the defendant. "Whoever claims is the one to adduce evidence", it's a principle provision of China's civil procedure law on the allocation of the burden of proof between the plaintiff and the defendant. Anti-monopoly civil litigation is a special law of general civil litigation. When there is no special provision in the law, the principle of "Whoever claims is the one to adduce evidence" must be followed.

\subsection{The Special Litigation of Abusing Market Dominant Position}

However, an abuse of market dominance action is not an ordinary civil action. It has significant special features. First of all, this special characteristic is manifested in the unequal status of persons and matters. The defendant in the case in question is often the leader in a particular industry and has a strong economic base. However, the plaintiff is usually a weak consumer or small business, and its energy and financial resources invested in litigation is often limited. Secondly, it is reflected in the asymmetry of information. In antitrust cases, the alleged monopoly operator is the producer of information. They have the advantage of information and the information they possess is hidden information.[3] Therefore, the valuable evidence for the plaintiff is often the top secret information of the defendant in litigation. The defendant may refuse to provide the relevant information for various reasons, such as "trade secrets". The course of the case is even determined by the seriousness of this information asymmetry. Finally, it reflects the professionalism and complexity of the determination of abusive conduct. Monopoly is originally a product of the development of the market economy, and its development necessarily has the integration of economics. In the antitrust law, many concepts belong to the concept of economics, for example, the determination of the abuse of dominant position in the market involves the relevant market, market power and the structure of the market. These concepts are not only interlocking and interlocking, but are also related to each other. At the same time, these concepts are all economic concepts. The judgement and analysis of these objects of proof cannot be resolved by legal knowledge alone. The tools and methods of economics and statistics must be used to obtain the relevant evidence. In addition, the experience and 
knowledge of experts must be drawn upon to meet the standards of civil proceedings. For the analysis of abusive conduct, the competitive situation in the market as a whole needs to be combined to make a comprehensive judgement. This is a highly complex process for the average plaintiff. To do so requires not only a basic knowledge of the law, but also a knowledge of, or even proficiency in, highly specialized areas of economics and statistics. As a result, the plaintiff has to incur substantial costs in providing a large amount of data, constructing economic models, hiring experts at high cost to give court presentations and producing economic analyses to prove this.

\subsection{Current Provisions on the Allocation of Burden of Proof}

The special nature of abuse of dominant position litigation is determined by these factors. The defendant is the typical party with too much evidence in its favour. In such circumstances, the plaintiff will face enormous difficulties in proving his case if the "he who claims, proves" rule of evidence is still applied. In other words, the case will be decided before it is even heard. If this is the case, abuse of dominance litigation will lose its relevance. The burden of proof on both sides must therefore be balanced. Abuse of dominant position is one of the types of tort. The four elements of violation, fact of damage, causation and fault in turn constitute tort liability.[4] Therefore, the analysis of the current provisions on the allocation of the burden of proof in abuse of dominant position litigation should start from these four elements and look for the relevant basis in the Anti-Monopoly Law and the 2012 Supreme People's Court's Provisions on Several Issues Concerning the Application of Law in Hearing Cases of Civil Disputes Arising from Monopolistic Conduct (hereinafter referred to as the Provisions), etc.

\subsubsection{Identification of Abuse}

Firstly, the abuse is proved. From the provisions of Article 17 of the Anti-Monopoly Law, it can be concluded that the plaintiff is required to prove the defendant's dominant market position and abusive conduct in an action for abuse of market dominance. The burden of proof for both the plaintiff and the defendant in a dispute is even more clearly defined in Article 8 of the Regulation: "The first paragraph of Article 17 of the Anti-Monopoly Law shall apply to the monopolistic act complained of. It provides that the plaintiff who abuses a dominant market position shall have a dominant position in the relevant market in which the defendant is located. And the burden of proof for the abuse of dominant position is on him. The defendant shall bear the burden of proof if he defends his conduct on the ground that it is justified." The determination of market dominance requires the plaintiff to prove that it is in the same relevant market as the defendant. This requires the plaintiff to complete the definition of a relevant market in accordance with the provisions of the Guidelines on the Definition of Relevant Markets. From the point of view of the evils of proof of market dominance, the provisions of Article 18 and Article 19 are a presumptive model for the analysis of the determination of market dominance and the reduction of the burden of proof in favour of the plaintiff. In Article 9 of the Regulation, the abuse of a dominant position by a public enterprise or other operator with an exclusive position under the law is provided for.

In Article 10 of the Regulation, the collection of evidence is regulated. "The defendant publishes information to the public that proves that it has a dominant position within the relevant market." And in both Article 12 and Article 13, the application of a professional is in principle a provision for a reduced burden of proof for the plaintiff.

\subsubsection{Identification of Damage results and Causality}

In Article 50 of the Anti-Monopoly Law and Article 14 of the Regulation, the provisions on damages are vague. But in its comparison with an ordinary action for damages, the plaintiff necessarily has to bear the burden of proof of the outcome of his own damage. At the same time, the necessary condition for constituting civil liability is a causal link between the violation and the damage. [5] However, no judge will usually focus on this one step in the reality of justice. This is because the plaintiff is generally unable to successfully meet the previous burden of proof.

\subsubsection{Identification of Fault}

The prevailing view in the United States is that almost all anti-competitive conduct is intentional. That is why the provision of fault is not mentioned in the damages of its antitrust legislation. And in our Anti-Monopoly Law and Regulation, the application of the principle of imputation is not explicitly stated. However, the provisions of Article 17 of the Anti-Monopoly Law are analyzed to show that the principle of no-fault liability is applied to the acts in paragraph 1 of this article. Paragraphs 2 to 6 of this article are based on the principle of presumption of fault. Once the perpetrator has committed these four types of acts, the element of fault for the act is absorbed by the element of the existence of the offence to be proved, in order to presume that it is at fault. It does not need to be proved by the plaintiff. [6] At the same time, abuses committed by market operators in pursuit of market 
monopolies and monopoly profits are necessarily intentional.

\section{EMPIRICAL ANALYSIS OF LITIGATION CASES OF ABUSE OF MARKET DOMINANCE}

From the above analysis of the current provisions on the burden of proof, it is clear that there are still a number of laws that theoretically reduce the plaintiff's burden of proof based on the specificity of cases of abuse of dominant position. How well do these rules work in judicial practice? Can the burden of proof of both the plaintiff and the defendant in a case really be balanced? Therefore, 46 final judgments in market dominance disputes were collected from the "China Judicial Documents Website". The text of the collected judgments is read and analyzed in detail (please see Table 1).

As can be seen from Table 1, there were only 4 successful cases out of 32. The win rate in the sample was only about $12.5 \%$. Of these four cases, Huawei v. IDC abuse of market dominance monopoly disputes was the most unusual. This is because the patents in question were unique in implementing the standard. So each standard-essential patent constitutes a separate relevant product market. In this case, the holder of the standard-essential patent has a $100 \%$ market share. Therefore, this person must have a dominant market position. The other three successful cases were all cases where the plaintiff used the deeming analysis to find market dominance by the defendant. In other words, the plaintiffs in these four successful cases did not use the deeming analysis to prove the defendant's market dominance. In the unsuccessful cases, the plaintiffs' definition of the relevant market was incorrect. In 23 cases, $71.9 \%$ of the sample, the proof of the defendant's dominant position could not be completed. This indicates that the vast majority of plaintiffs had serious problems in proving the definition of the relevant market and market dominance, either through insufficient proof or inability to prove it.

In summary, the success rate of plaintiffs in abuse of dominant position litigation is extremely low. In the cases where the plaintiff lost, the plaintiff was unable to accurately define the relevant market and to prove the defendant's dominant market position. This is the main reason for losing cases. This is why it is so difficult to prove abuse of evidence and so difficult for plaintiffs to investigate and obtain evidence. Evidence is not only the core of civil litigation, but also a powerful weapon for the parties to defend their legitimate rights and interests. [7] If the plaintiff cannot and insufficient evidence and lost and it has become a common phenomenon, it is necessary to reflect on the plaintiff's burden of proof is too heavy, as well as the existing rules for the allocation of evidence whether there is an imbalance in the phenomenon.

\section{THE ANALYSIS OF THE CAUSES OF THE IN THE ALLOCATION OF BURDEN OF PROOF}

\subsection{Imperfection of the Existing Rules on the Mitigation of Burden of Proof}

The reduction of the burden of proof is based on the recognition of the objective role of the burden of proof. From the perspective of the subjective burden of proof level, the subjective burden of proof of both parties should be reasonably distributed, the weak position of the party with the burden of proof should be compensated, and their difficulties in the process of proving the lawsuit should be alleviated. The dilemma of deciding on the objective burden of proof applies across the board when the truth of the facts of a case is unclear. The reversal of the burden of proof [8] is a redistribution of the risk of losing a case where the truth or falsity of the facts is unknown between the parties. For those cases where the facts are particularly difficult to prove, the reversal of the burden of proof is often what changes the outcome between winning and losing the case. The standard of allocation of the burden of proof is arbitrarily altered by this practice, which can lead to a loss of legal certainty. Moreover, it completely abandons the general principle of allocation of proof. Moreover, reversal of the burden of proof does not necessarily lead to substantial justice. [9] And it so happens that the partiality dilemma of evidence is not concerned with the objective burden of proof of the facts to be proved not meeting the standard of proof, but rather with the question of how to maximize justice by adjusting the allocation of the subjective burden of proof. [10] In other words, the dilemma of proof for the plaintiff in a typical case of abuse of market dominance litigation needs to be solved by adjusting the subjective burden of proof to improve the existing burden of proof reduction provisions, not by choosing to change the objective allocation of the burden of proof. Article 19 of the Anti-Monopoly Law and Articles 9 and 10 of the Regulations are the application of the technique of burden of proof reduction in the field of abuse litigation. However, it is clear that none of these provisions have had the effect that the legislator intended them to have.

\subsubsection{Difficulties in the Application of the Presumption of Market Dominance Rule}

Article 19 of the Anti-Monopoly Law is a presumption rule for the defendant's dominant market position, which is obviously theoretically conducive to reducing the plaintiff's burden of proof and improving judicial efficiency, as the plaintiff only needs to 
complete the proof of the defendant's market share in order to presume the defendant's dominant market position. However, an empirical analysis of the cases shows that there is uncertainty as to whether this presumption rule can be applied, and that the courts have taken opposite paths of analysis. For example, in the case of Shengzhou Haoyunlai Company and Xinzhonggang Company's abuse of dominant market position, even though there was only one cogeneration enterprise in Shengzhou with a $100 \%$ market share, the court did not directly apply the presumption rule to determine the defendant's dominant market position, but held that it still needed to be determined on a case-by-case basis in light of the market structure and competitive situation. In contrast, in the refusal to deal dispute between Yunnan Yingding and Sinopec Yunnan, Sinopec, the court relied directly on Article 19 to presume the defendant's dominant market position. It is thus clear that there is no uniform path of analysis among the courts as to the application of the presumption rule in respect of market dominance, and even if the plaintiff can prove that the defendant's market share meets the statutory standard, the courts may find that there are circumstances in which the presumption rule does or does not apply.

\subsubsection{Article 9 of the Regulation is Vaguely Defined}

Article 9 of the Regulation establishes a presumption of market dominance for public enterprises or other operators with an exclusive position under the law. In practice, however, this provision still did not serve to reduce the plaintiff's burden of proof. In the case of Ding Qidong and Unicom Beijing's refusal to deal, the court of first instance held that the nature of the defendant Unicom Beijing's business fell under the category of "public enterprises" in accordance with Article 2 of the then-unrepealed "Certain Provisions on Prohibiting Restrictions on Competition by Public Enterprises". However, the court of second instance overturned this finding, holding that whether the market was a natural monopoly or a more competitive market was an important distinction between public enterprises and other enterprises, and that effective competition had already been established in the telecommunications service industry, so the defendant should not be classified as a public enterprise. It can be seen that there was a lot of debate between the courts on the definition of a public enterprise in the first place. The definition of a public enterprise is set out in Article 22 of the Interim Provisions on the Prohibition of Abuse of a Dominant Market Position issued by the State Administration of Market Supervision and Administration, but it is easy to see that this is not very different from the definition of a public enterprise in Article 2 of the repealed Provisions on the Prohibition of Restrictions on Competition by Public Enterprises, both of which use a general and enumerated approach to define the meaning of a public enterprise, and that the Chinese word for public enterprise corresponds to the English word "public utilities", which can be translated as both public enterprises and public utilities, or public enterprises and public utilities are synonymous and refer to the same thing. [11] In this way, public enterprises are now defined tautologically, which not only fails to reveal the intrinsic nature of public enterprises, but also tends to have the worry of hanging on to one thing, and does competition not exist in public enterprises? From the Beijing High People's Court's decision, it is clear that its view is that only natural monopolies are public enterprises, but is this view correct? "Market competition is ultimately established in the public enterprise market and its status cannot be shaken." [12] For this reason, it is clear that public enterprises are not free from competition; let alone indeterminate their nature as public enterprises on the basis of the existence of a certain amount of competition in a certain industry. Secondly, in the case of Haoyunlai Company and Xinzhonggang Company, the court required the plaintiff to prove that the defendant was a public enterprise, in addition to the market structure and competition, in order to establish dominant market position. In the case from $\mathrm{Wu}$ Zongqu, on the other hand, the court directly found the defendant's dominant market position. Therefore, the conditions for the application of Article 9 are clearly inadequate in the determination of the defendant's dominant market position. And the latter part of the provision is equally incoherent - what factors are specifically included in the market structure and competitive situation? Who should provide such evidence?

\subsubsection{Lack of Probative Power of "Confession" Evidence}

In the case of Wang Linlin and the Lianjia company, Zhong Rongxin abused its dominant market position, even though the plaintiff provided notarized evidence published on the defendant's official website sufficient to prove its dominant market position, the court held that the evidence was formed outside the litigation and that the plaintiff could not prove that the evidence was scientific and objective, so the court did not accept the evidence.Moreover, in the case of the monopoly dispute between Tongyuan and Taizhou Petrochemical Company, the plaintiff provided evidence of the defendant's dominant market position, which was published on the internet, and the court not only rejected the probative value of the evidence, but also held that the evidence did not meet the formal requirements of the evidence and was therefore inadmissible. In this regard, it can be seen that the provisions of Article 10 
are difficult to be successfully applied by the plaintiff and can play a minimal role, as there are many restrictions on the use of information published by the defendant as evidence.

In summary, even if the existing law on the plaintiff's burden of proof made a certain tilted provisions. But in the judicial status quo, these provisions play a less than satisfactory effect.

\section{LEGISLATIVE FORESIGHT ON THE ALLOCATION OF THE BURDEN OF PROOF IN MARKET DOMINANCE LITIGATION}

\subsection{Improvements to the Existing Rules on Reducing the Burden of Proof}

In the face of today's abuse of the plaintiff's burden of proof dilemma, some scholars believe that the plaintiff's burden of proof dilemma in monopoly cases should be solved through the inversion of the burden of proof: "Antitrust civil litigation is more special, and it cannot be applied to the general rule of allocation of the burden of proof in civil litigation. The inversion of the burden of proof system should be implemented to allocate part of the burden of proof that should have been borne by the plaintiff to the defendant." [13] However, the author does not agree with the inversion of the burden of proof to solve the problem of the plaintiff's difficulty in proving, the reckless allocation of the burden of proof is not a long-term solution to the dilemma of proof, from the improvement of the existing rules to reduce the burden of proof is the right solution.

First of all, it is the presumption of market dominance rule in Article 19 of the Anti-monopoly Law. Although the legislative intent is to reduce the burden of proof on the plaintiff, the application of this presumption rule has been rather ineffective in empirical evidence. There are often different views among courts as to whether the presumption can be directly relied on in terms of market share, so much so that this provision has had different paths of analysis in judicial practice. Therefore, the author believes that in order for this provision to be truly effective, it is necessary for the courts to form a unified analytical path for the application of the provision, that is, Article 19 of the Anti-Monopoly Law should delete the word "may" from the provision and unify the analytical framework of the courts, so that when the plaintiff has sufficient evidence to prove that the defendant's When the plaintiff has sufficient evidence that the defendant's market share meets the statutory criteria, the court must apply the presumption rule and presume the defendant's market dominance, shifting the burden of proof to the defendant to produce evidence to the contrary, rather than leaving the court free to rule that the defendant's market dominance is to be analyzed in accordance with Article 18 even if the required market share is met.

Secondly, Article 9 of the Regulation should be improved. It can be concluded from empirical cases that there are also a number of obstacles to the applicability of this provision. Firstly, the current academic debate on the substantive concept of a public enterprise has led different courts to take different views on the applicability of this provision. Therefore, the author believes that the definition of a public enterprise should now be clarified in the relevant law. Moreover, a distinction should be made between a public enterprise that is a natural monopoly and a public enterprise that has a competitive business. When the plaintiff proves that the defendant is the only natural monopoly in the market, the defendant's dominant position is presumed, leading to a transfer of evidence. The defendant may raise a defence to this. When the plaintiff proves that the defendant is a public enterprise with a competitive business, the plaintiff needs to provide additional market structure or competition in order to prove market dominance.

Finally, Article 10 of the Regulation should be amended. In my view, if the plaintiff presents prima facie evidence of the defendant's external publication of information that proves its dominant market position, and that evidence matches the relevant market in question, the court should find the evidence valid and shift the burden of proof to the defendant. If the court finds that the prima facie evidence is insufficient to prove that it matches the relevant market in question, the plaintiff should be allowed to apply to the court for access to the full information disclosed by the defendant for use as evidence, thereby reducing the plaintiff's burden of proof. In addition, the formal elements of evidence need to be clarified in the Regulation, such as whether notarization is required.

\section{CONCLUSION}

The rules on the allocation of the burden of proof are crucial for plaintiffs in abuse of dominance litigation. The special nature of abuse cases leads to an imbalance in the ability of both the plaintiff and the defendant to prove their case. If the burden of proof is not properly allocated, the correct outcome of the case will be directly affected and fairness and justice will be at stake. At the same time, it can make it difficult to conduct an abuse of dominance action, thus making it difficult to realize the value of private anti-trust litigation. Therefore, the existing provisions in the abuse of dominant position litigation must be improved by reducing the burden of proof as an entry point, in order to solve the dilemma in practice, maintain the freedom of the market and fair competition order, as well as to promote the realization of the value of antitrust 
litigation, so as to make the development of antitrust law better.

\section{REFERENCES}

[1] Li Hao. The allocation of the burden of proof in civil judgments: an analysis of the Gazette case as a sample. Tsinghua Law Review, No. 6, 2008.

[2] [US] Michael D. Bayles. Translated by Zhang Wenxian et al. (1996). Principles of Law : A Normative Analysis, pp. 67-68. Encyclopedia of china publishing house.

[3] Yin Jiguo. The Legal Regulation of Information Asymmetry in Antitrust Evidence. Economic Law Review, No. 1, 2015.

[4] Yang Lixin. (2011). Treatise on Tort Law (4th ed.), p. 158. People's Court Press.

[5] Yu Nengbin \& Ma Junju. (1995). Modern Civil Law, p. 669. Wuhan University Press.

[6] Yuan Xiaolei. On the Dilemma of the Burden of Proof and Countermeasures for Private Litigation on Abuse of Market Dominance. Journal of China University of Political Science and Law, No. 4, 2019.

[7] Xiao Jianhua. The Jurisprudence of Civil Procedure. Xiamen University Press edition published in 2011, pp. 186-189.
[8] Wei Qingyu. (2013). The Theory of Reduced Burden of Proof. Shanghai, Shanghai Jiaotong University, $\mathrm{PhD}$ thesis.

[9] Hu Xuejun. (2014). A Theory of Specific Burden of Proof, p. 122. Law Press.

[10] Huang Guochang. New Developments in the Theory of Civil Litigation. The 2008 edition of Peking University Press, p. 144.

[11] Kong Xiangjun. Understanding and Application of China's Current Anti-Monopoly Law. 2001 edition of People's Court Press, p. 44.

[12] Yao Baosong. Study on the Antitrust Legal Regulation of Public Enterprisesd, the 2014 edition of the Law Press, p. 415.

[13] Li Guohai. A Review of the System for Allocating the Burden of Proof in Antitrust Civil Litigation in China - A Typical Case as a Sample. Journal of Jishou University (Social Science Edition), No. 1, 2019. 
Table 1.

\begin{tabular}{|c|c|c|c|c|c|}
\hline \multirow[b]{2}{*}{ Name of the case } & \multicolumn{3}{|c|}{$\begin{array}{l}\text { The burden of proof of the } \\
\text { plaintiff }\end{array}$} & \multirow[b]{2}{*}{$\begin{array}{l}\text { Did the } \\
\text { defendant } \\
\text { adduce } \\
\text { evidence } \\
\text { that } \\
\text { Justificati } \\
\text { on of } \\
\text { conduct }\end{array}$} & \multirow[b]{2}{*}{$\begin{array}{l}\text { Whether } \\
\text { the } \\
\text { plaintiff } \\
\text { won the } \\
\text { case }\end{array}$} \\
\hline & $\begin{array}{l}\text { Whether } \\
\text { the } \\
\text { relevant } \\
\text { market is } \\
\text { accurately } \\
\text { defined }\end{array}$ & $\begin{array}{l}\text { Whether the } \\
\text { burden of } \\
\text { proof that the } \\
\text { defendant has } \\
\text { a dominant } \\
\text { market } \\
\text { position is } \\
\text { met }\end{array}$ & $\begin{array}{l}\text { Whether } \\
\text { the burden } \\
\text { of proof for } \\
\text { the } \\
\text { defendant's } \\
\text { abuse of a } \\
\text { dominant } \\
\text { market } \\
\text { position is } \\
\text { met }\end{array}$ & & \\
\hline $\begin{array}{l}\text { Dispute concerning abuse of dominant } \\
\text { market position between Wang Linlin and } \\
\text { Beijing Lianjia Real Estate Brokerage Co., } \\
\text { Ltd. }\end{array}$ & No & No & No & No need & No \\
\hline $\begin{array}{l}\text { Disputes over Abuse of Market } \\
\text { Dominance and Unfair Competition } \\
\text { between Guangzhou Huaduo Network } \\
\text { Technology Co., Ltd and Guangzhou } \\
\text { Netease Computer System Co., Ltd }\end{array}$ & No & No & No & No need & No \\
\hline $\begin{array}{l}\text { Disputes over the Abuse of Market } \\
\text { Dominance between Yunnan Damingxing } \\
\text { Happy Park Entertainment Co., Ltd., and } \\
\text { China Audiovisual Copyright Collective } \\
\text { Management Association, Yunnan Tianhe } \\
\text { Century Cultural Communication Co., Ltd. }\end{array}$ & Yes & Yes & No & No need & No \\
\hline $\begin{array}{l}\text { Dispute of abuse of dominant market } \\
\text { position between Siping Branch of Jilin } \\
\text { Longda Heat Power Co., Ltd. and Siping } \\
\text { Thermal Power Co., Ltd. }\end{array}$ & Yes & Yes & No & No need & No \\
\hline $\begin{array}{l}\text { Dispute over the Abuse of Market } \\
\text { Dominance between Yang Zhiyong and } \\
\text { China Telecom Co., Ltd., Shanghai Branch } \\
\text { of China Telecom Co., Ltd. }\end{array}$ & No & No & No & No need & No \\
\hline $\begin{array}{l}\text { Dispute over Abuse of Market Dominance } \\
\text { between Beijing Mishi Technology Co., } \\
\text { Ltd and Beijing Qihu Technology Co., Ltd }\end{array}$ & No & No & No & No need & No \\
\hline $\begin{array}{l}\text { Dispute over abuse of dominant position } \\
\text { between Tong Hua and China Mobile } \\
\text { Communications Group Shanghai Co., } \\
\text { Ltd. }\end{array}$ & No & No & No & No need & No \\
\hline $\begin{array}{l}\text { Dispute concerning abuse of dominant } \\
\text { position in the market between Ningbo } \\
\text { Keyuan Plastics Co., Ltd and Ningbo } \\
\text { Lianeng Heating Co., Ltd. }\end{array}$ & No & No & No & No need & No \\
\hline $\begin{array}{l}\text { A case of abuse of dominant market } \\
\text { position between Chen Guiying and } \\
\text { Guangdong Yantang Dairy Co., Ltd. }\end{array}$ & No & No & No & No need & No \\
\hline $\begin{array}{l}\text { The dispute case of refusal to trade in } \\
\text { Xiangshan Jieda Network Technology } \\
\text { Service Department }\end{array}$ & No & No & No & No need & No \\
\hline $\begin{array}{l}\text { Dispute over bundled transactions between } \\
\text { Wu Xiaoqin and Shanxi Radio and } \\
\text { Television Network Media (Group) Co., } \\
\text { Ltd }\end{array}$ & Yes & Yes & Yes & No & Yes \\
\hline $\begin{array}{l}\text { Dispute case of refusal to deal between } \\
\text { Taizhou Huangyan Shusheng Xien } \\
\text { Network Technology Service Department } \\
\text { and China Internet Network Information } \\
\text { Center }\end{array}$ & No & No & No & No need & No \\
\hline
\end{tabular}




\begin{tabular}{|c|c|c|c|c|c|}
\hline $\begin{array}{l}\text { Huawei v. IDC abuse of market dominance } \\
\text { monopoly disputes }\end{array}$ & Yes & Yes & Yes & No & Yes \\
\hline $\begin{array}{l}\text { A monopoly dispute on abuse of market } \\
\text { dominance between Huzhou Yiting } \\
\text { Termite Control Service Co., Ltd. and } \\
\text { Huzhou Institute of Termite Control Co., } \\
\text { Ltd. }\end{array}$ & No & No & No & No need & No \\
\hline $\begin{array}{l}\text { Monopoly disputes between Gaoyou } \\
\text { Tongyuan Oil Transportation Co., Ltd. and } \\
\text { Taizhou Petrochemical Co., Ltd. }\end{array}$ & No & No & No & No need & No \\
\hline $\begin{array}{l}\text { Beijing Qihu Technology Co., Ltd. v. } \\
\text { Tencent Technology ( Shenzhen ) Co., Ltd. } \\
\text { and Shenzhen Tencent Computer Tencent } \\
\text { Computer System Co., Ltd. concerning the } \\
\text { abuse of market dominance }\end{array}$ & No & No & No & No need & No \\
\hline $\begin{array}{l}\text { Dispute over the Abuse of } \text { Market } \\
\text { Dominance by Tangshan } \\
\text { Information Service Co., Ltd. v. Beijing } \\
\text { Baidu Network Technology Co., Ltd. }\end{array}$ & Yes & No & No & Yes & No \\
\hline $\begin{array}{l}\text { The monopoly disputes between Liu } \\
\text { Dahua and Hunan Huayuan Industrial Co., } \\
\text { Ltd., Dongfeng Motor Co., Ltd., and } \\
\text { Dongfeng Nissan Passenger Car Co., Ltd. }\end{array}$ & No & No & No & No need & No \\
\hline $\begin{array}{l}\text { Dispute over abuse of market dominance } \\
\text { between Pan Yao and Shanghai } \\
\text { International Commodity Auction Co., } \\
\text { Ltd. }\end{array}$ & No & No & No & No need & No \\
\hline $\begin{array}{l}\text { Dispute over abuse of dominant market } \\
\text { position between Song Xin and China } \\
\text { Railway Corporation }\end{array}$ & No & No & No & No need & No \\
\hline $\begin{array}{l}\text { Dispute of refusal to deal between Jing } \\
\text { Jiao and Beijing Branch of China United } \\
\text { Network Communication Co., Ltd }\end{array}$ & No & No & No & No need & No \\
\hline $\begin{array}{l}\text { Telecommunication Service Contract } \\
\text { Dispute Case between Tao Zhihai and } \\
\text { Zhangjiakou Branch of China United } \\
\text { Network Communication Co., Ltd }\end{array}$ & No & No & No & No need & No \\
\hline $\begin{array}{l}\text { The dispute on the bundled transaction } \\
\text { between Xu Liang and Qingdao Tongbao } \\
\text { Automobile Co., Ltd. }\end{array}$ & No & No & No & No need & No \\
\hline $\begin{array}{l}\text { Dispute over the abuse of market } \\
\text { dominance by Wu Zongli and Yongfu } \\
\text { County Water Supply Company }\end{array}$ & Yes & Yes & Yes & Yes & Yes \\
\hline $\begin{array}{l}\text { Dispute over abuse of market dominance } \\
\text { between Wu Zongqu and Yongfu County } \\
\text { Water Supply Company }\end{array}$ & Yes & Yes & Yes & Yes & Yes \\
\hline $\begin{array}{l}\text { Disputes over refusal of transactions } \\
\text { between Yunnan Yingding Bioenergy Co., } \\
\text { Ltd., and Sinopec Yunnan Branch, Sinopec }\end{array}$ & No & Yes & No & No need & No \\
\hline $\begin{array}{l}\text { Disputes over the abuse of market } \\
\text { dominance between Shengzhou Haoyunlai } \\
\text { Company and Xinzhonggang Company }\end{array}$ & Yes & No & No & No need & No \\
\hline $\begin{array}{l}\text { The dispute on refusal to trade between } \\
\text { Ding Qidong and the Beijing branch of } \\
\text { China United Network Communications } \\
\text { Co., Ltd. }\end{array}$ & No & No & No & No need & No \\
\hline $\begin{array}{l}\text { Dispute over the contract for the licensing } \\
\text { of copyright and monopoly between Zhang } \\
\text { Kaiping and NetEase }\end{array}$ & No & No & No & No need & No \\
\hline $\begin{array}{l}\text { Dispute over refusal to deal between } \\
\text { Xiangshan Jieda Network Technology }\end{array}$ & No & No & No & No need & No \\
\hline
\end{tabular}




\begin{tabular}{|c|c|c|c|c|c|}
\hline $\begin{array}{l}\text { Service Department and the Internet } \\
\text { Centre }\end{array}$ & & & & & \\
\hline $\begin{array}{l}\text { The monopoly dispute between Beijing } \\
\text { Shusheng Electronic Technology Company } \\
\text { and Shengda Company, Xuanting } \\
\text { Company }\end{array}$ & No & No & No & No need & No \\
\hline $\begin{array}{l}\text { Dispute over abuse of market dominance } \\
\text { between Panjin Dongxing Company and } \\
\text { CNPC, BECKBURY Company }\end{array}$ & No & No & No & No need & No \\
\hline
\end{tabular}

